\section{Relationship between gray directors and executive compensation in Indian firms}

Gray directors and executive compensation

Krishna Prasad and K. Sankaran

Justice KS Hegde Institute of Management, Nitte, India, and

Nandan Prabhu

Manipal Institute of Management, Manipal Academy of Higher Education, Manipal, India
Received 5 November 2017 Revised 23 May 2019 Accepted 30 May 2019

\begin{abstract}
Purpose - The purpose of this paper is to examine the empirical relationship between gray directors (non-executive non-independent directors) and executive compensation among companies listed in India's National Stock Exchange (NSE). The paper also examines the possible interplay of relationships between controlling shareholder duality (controlling shareholder being the CEO), ownership category and executive compensation.

Design/methodology/approach - A sample of 438 firms listed in the NSE of India was studied using data spanning five financial years, 2012-2013 to 2016-2017.

Findings - Empirical evidence suggests that there is a positive association between the proportion of gray directors on the board and executive compensation. The sensitivity of executive compensation to gray directors is found to be higher among family controlled firms. This research has also found that CEOs who belong to controlling shareholder groups received higher pay than professional CEOs. The authors conjecture that these results suggest cronyism and may contribute to lower levels of corporate governance practices in the country.

Research limitations/implications - The hybrid board structure, which India has adopted with the desire to bring the best of Anglo Saxon and Japanese board philosophies, has paradoxically led to self-serving boards. Exploration of alternative thinking to bring about changes in the regulatory framework is, therefore, necessary.

Originality/value - Serious problems are identified with the philosophy behind board composition mandated by Listing Requirements for Indian firms with empirical evidence showing how the existing rules generate cronyism and unfairness to minority shareholders.
\end{abstract}

Keywords CEO pay, Controlling shareholder duality, Gray directors,

Non-executive non-independent directors

Paper type Research paper

\section{Introduction}

In India, corporate ownership is predominantly in the hands of domestic individuals and families (Balasubramanian and Ramaswamy, 2013). However, institutions, governments and foreign entities also hold their respective stakes in Indian companies. Against this background, the salaries of CEOs of firms held by domestic individuals and families are found to be higher than those of others. Studies have shown that the compensation of CEOs who are

(C) Krishna Prasad, K. Sankaran and Nandan Prabhu. Published in European Journal of Management and Business Economics. Published by Emerald Publishing Limited. This article is published under the Creative Commons Attribution (CC BY 4.0) licence. Anyone may reproduce, distribute, translate and create derivative works of this article (for both commercial and non-commercial purposes), subject to full attribution to the original publication and authors. The full terms of this licence may be seen at $\mathrm{http} / / /$ creativecommons.org/licences/by/4.0/legalcode

The authors acknowledge and thank the financial support provided by Nitte Education Trust, Mangaluru, India for completing this research. Authors are thankful to the anonymous reviewers for their insightful comments.

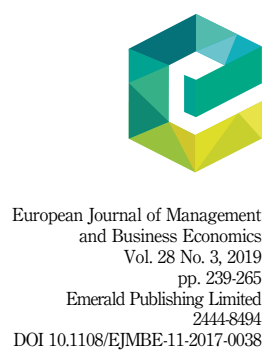


EJMBE

28,3

240

controlling shareholders is generally higher than that of professional CEOs (Parthasarathy et al., 2006; Ramaswamy et al., 2000). This phenomenon of excessive CEO compensation, which appears to be dominant in family controlled firms, assumes importance because of governance implications that warrant research attention. CEO compensation and agency conflict have many implications that generate other agency costs.

The issue of excessive and unabashedly high CEO compensation has been a matter of public debate especially in countries like the USA, and also in the corporate world in general across the globe. Corporate governance requirements vis-à-vis board composition and norms regarding the appointment of independent directors are expected to address the problem of excessive CEO compensation. However, evidence of the effectiveness of such measures remains mixed. In this paper, we posit that the factors that demonstrate the possible relationship between the nature of board composition and CEO compensation are different in the Indian context. Boards of Indian companies consist of a mix of independent directors, executive directors and gray directors. This kind of board mixture is also often characterized by the absence of within-board pressure and expression of the voice of dissent. However, in general, appositive pressure of dissenting opinions and expressions of dissent within corporate boards are missing in the Indian context. The absence of a purposeful voice of dissent implies that something which is of great utility from the standpoint of maintaining corporate governance standards, is absent. Therefore, it is necessary to investigate the association between the characteristics of board composition and CEO compensation.

Accordingly, this paper examines two crucial issues related to the nature of boards in the Indian context. First, it seeks to investigate whether the presence of gray directors on the corporate board has any association with the magnitude of CEO compensation. Gray directors are demarcated on the basis that they are neither executives nor independent directors (Borokhovich et al., 2014; Hsu and Wu, 2014). We suspect that CEOs may collude with gray directors in fixing $\mathrm{CEO}$ compensation leading to adverse corporate governance and unfair treatment of minority shareholders.

Second, this paper investigates whether there would be any change in the relationship between the presence of gray directors on corporate boards and CEO compensation across different ownership categories. Accordingly, we investigate the association between board composition that is characterized by the presence of gray directors and the magnitude of CEO compensation among different ownership categories of Indian companies. It may be noted that the majority of Indian firms are family owned and very few firms are controlled by professional management. Therefore, investigation of the likely adverse impact of ownership structure and board composition is also significant to protect the interest of minority shareholders.

Though there are studies that have investigated the relationship between independent directors and $\mathrm{CEO}$ compensation, the literature on the relationship between gray directors and the CEO compensation is limited. This is evident from a close scrutiny of prior research on gray directors that has investigated its association with variables such as firm value and performance (Choi et al., 2007; Khan et al., 2012; Kumar and Singh, 2012; Srivastava, 2015; Yammeesri and Herath, 2010; Zakaria et al., 2010), board composition and corporate governance (Borokhovich et al., 2014; Carcello and Neal, 2000; Clifford and Evans, 2002; Core et al., 1999; Raghunandan et al., 2001; Ryan and Wiggins, 2004; Sarkar, 2009; Sarpal, 2015; Shivdasani and Yermack, 1999) and earnings management and fraud (Beasley, 1996; He et al., 2009; Houston et al., 2016; Hsu and Wu, 2014). To the best of our knowledge, this is the first study of its kind in the Indian context that has attempted to understand the relationship between gray directors and excessive CEO compensation across different categories of board composition.

Exploring the relationship between the presence of gray directors and CEO compensation is significant for several reasons. First, the presence of gray directors may be causing excessive payments to CEOs incommensurate with their performance and 
industry standards. More generally, directors who are supposed to oversee the performance of their firms may have to address the issue of a conflict of interest as the "overseer," and the "overseen" would be the same. Second, the presence of gray directors is likely to be a cause of concern for investors and minority shareholders who might perceive the role of the board to be unfavorable to them (Zhao and Brehm, 2011). Third, gray directors may be "related" to their CEOs. Here, the insidious nature of the conflict of interest is evident. Finally, there is also the issue of controlling shareholder duality, i.e., CEO being a controlling shareholder of the firm, which may hurt other shareholders (Chakrabarti et al., 2012). As such, we also examine the effect of controlling shareholder duality and CEO compensation across different ownership categories.

Prior research (e.g. Chauhan et al., 2016) has found that Indian family controlled firms exhibit a lower degree of board independence in comparison with management-controlled firms (MCF). The relationship between lower board independence and excessive CEO compensation may not become such a matter of concern if executive compensation is commensurate with profits earned by the company in question. However, this is not so in the Indian context (Ghosh, 2006; Narayanan and Dubey, 2015). Specifically for family owned companies, Raithatha and Komera (2016) have shown that executive compensation has no association the performance of family controlled firms. In contrast to this, nonfamily firms, run by professional managers place more emphasize on pay-for-performance (Saravanan et al., 2017).

There are several contributions that this paper makes to the literature on executive compensation. First, it is revealed that there exists a significant association between the presence of gray directors and CEO pay in family controlled firms. In this connection, we also investigate whether and how the presence of gray directors in Indian companies is associated with CEO compensation across different ownership categories. This is accomplished by dividing Indian corporate firms into different groups based on firm ownership.

Second, we show empirical evidence of the positive association between the presence of gray directors and executive compensation. This paper situates the research discourse on gray directors on the theoretical rationale of psychological contract theory while explaining why several theories of executive compensation fail to account for the relationship between gray directors and unduly excessive executive compensation. In this respect, this paper goes beyond agency theory, stewardship theory, and a broad spectrum of theories of executive compensation to theoretically explain the phenomenon of excessive executive compensation using psychological contract theory. At last, this paper extends the research conversation on gray directors by going beyond the prior research areas of: association between gray directors and firm value/performance; association between gray directors; board composition and corporate governance; and association between gray directors, earnings management and corporate fraud.

The remainder of the paper is organized into six sections. In the second section, we review the literature and provide the theoretical underpinnings for further empirical treatment of the topic. In doing so, we examine prior empirical evidence on board and ownership structure, CEO compensation and firm performance. Furthermore, we analyze different theories of executive compensation. In this context, we show why these theoretical explanations of executive compensation and the broader approaches, which categorize the theoretical narratives of executive compensation, fail to account for the relationship between gray directors and the magnitude of executive compensation. We also discuss the appropriate theoretical perspectives that explain the hypothesized association between gray directors and executive compensation. Also, we discuss the implications of prior research on gray directors while showing how this paper extends the research conversation on gray directors. In the third section, we develop hypotheses and state the constructs of this study as also the control variables that we use. We describe the selection of variables and sampling issues in the fifth
Gray directors and executive compensation 
EJMBE

28,3

242

section. In the sixth section, we document the empirical results of the association between the level of compensation and explanatory variables. And the final section provides a summary, conclusions, contributions to the literature and policy implications.

\section{Literature review and theoretical underpinnings}

Findings of prior research are noteworthy in the context of the relationship between gray directors and executive compensation. For example, Core et al. (1999) examine the effect of gray directors on standards of corporate governance, CEO compensation and firm performance. For this purpose, their study used a sample of 495 firms in the USA with findings suggesting that the presence of gray directors reduces the standard of corporate governance. Therefore, they call for improving the quality of corporate governance by eliminating gray directors. Clifford and Evans (2002) show that the combination of inside directors and gray directors constitutes the majority of boards of a sample of Australian firms. Those authors conclude that the presence of gray directors would compromise the objectivity and effectiveness of corporate boards. In the South Korean context, Choi et al. (2007) indicate that the presence of independent directors maximizes firm performance in stock markets while the presence of gray directors does not lead to higher firm performance. Srivastava (2015) shows that the presence of gray directors in no way corresponds to higher firm performance in the Indian context. The absence of a positive association between the presence of gray directors and higher firm performance is also evident among Malaysian (Zakaria et al., 2010) and Thai (Yammeesri and Herath, 2010) firms.

Board of directors are expected to act as representatives of shareholders to minimize agency costs (Fama and Jensen, 1983). Accordingly, regulators in countries like the USA have mandated that public companies should constitute boards in such a manner that the majority of directors should meet requirements of the notion of independence[1]. However, there is an alternative view. According to this, independent board composition is likely to be problematic from the standpoint of what independent directors can offer to corporate value maximization in terms of their expertise. In line with such an argument, Miwa and Ramseyer (2005) observe that "What outsiders offer in independence, they sacrifice in expertise. The more independent they are, the less they know about the firm" (p. 300). Insufficient expertise of independent directors is the premise on which Japanese companies constitute their boards. In Japan, boards largely consist of insiders or top executives as members of the board. Even a cursory look at board compositions of American and Japanese firms shows that independent directors dominate the American model whilst inside director-executives play a prominent role in Japanese corporate boards. While agency theory is the foundational premise of the USA model, what drives Japanese board composition is stewardship theory (Ueda, 2015).

Though both these theories have noteworthy limitations, their relevance is undeniable. Empirical studies have shown that both models add value to firms (Jensen and Meckling, 1976; Miwa and Ramseyer, 2005) in their unique ways. Accordingly, there have been attempts to integrate the governance implications of both these theories to address the problem of agency conflicts. For example, the Indian model of board composition appears to be an amalgam of both these models.

The Securities and Exchange Board of India (SEBI) requires that all listed firms should have a corporate board with an optimum combination of inside and outside directors. SEBI's regulations stipulate that the percentage of outside directors should not be less than 50 percent of the total number of directors on a corporate board and the chairman of the board should be an outsider. Furthermore, the number of independent directors should not be less than 30 percent of the total number of directors if the chairman of the board is an outsider. The role of non-executive independent directors is meant to reduce agency costs while the function of the executive (inside) directors is to provide intellectual assistance in 
taking strategic decisions. SEBI effected these changes in its related statutes (Clause 49 of the Listing Agreement) in the wake of the submission of a report in 1999 by a high-powered committee set up by the government. The objective of these regulations is, understandably, to institutionalize the notion of "independence" in the board structure itself.

While there are clear guidelines on who could be the outside directors (independent directors), there are no restrictions on the remaining 50/70 percent of directors. Accordingly, these could all be executives or a mix of executives and non-executives. This ambiguous mandate regarding non-independent directors has given rise to another class of individual directors, i.e., non-executive, non-independent directors (Quadrant 4 in Table I).

Theoretically, Quadrant 1 cannot exist at all since no executive can be "independent." The definition of the independent director as per Clause 49 of Listing Agreement states that "independent director' means a non-executive director of the company [...]" (Sarkar, 2009). A director becomes truly independent if he/she is free from any conflict of interest in his/her dealings with the company. Accordingly, the person should be able to express the voice of dissent, if necessary, in a free manner. Therefore, we have categorized Quadrant 1 as not applicable (na).

If the corporate board is dominated by an "objective outsider," as indicated in Quadrant 2, the underlying assumption is that those directors provide a control function. In this case, we can draw underlying theoretical premises from agency theory. As opposed to this, domination by "benevolent insiders" (Quadrant 3) presupposes underlying support from stewardship theory. Maassen (1999) points out this distinction, mentioned above, as the underlying theoretical inspiration to draw a line of demarcation among directors. It is interesting to note that there are board structures which are available to provide for both control and expertise functions as in the case of Chinese companies. For example, Chinese law allows for a two-tier board system consisting of an advisory board of directors and a supervisory board (Conyon and He, 2011), the former providing the advisory function and the latter, the expertise function.

"Gray directors" appear in Quadrant 4 because there is no explanation in the literature regarding the nature of their role and $\mathrm{Hsu}$ and $\mathrm{Wu}$ (2014) define these actors as the non-executive directors who are not independent directors. Anderson and Reeb (2004) define gray directors as those directors with existing or potential ties to the firm. For instance, those board members who may have been functioning as gray directors might be former employees of the company, relatives of controlling shareholders, investment bankers and so on (Sarkar et al., 2012). Consequently, gray directors are non-independent, non-executive directors who are not "independent." In the regulatory filings of companies, ordinarily, directors are classified as either independent or non-independent directors. This classification disguises the presence of gray directors. In this connection, Houston et al. (2017) find that the boards of 51 percent of the SP 500 firms of USA had gray directors during 2000-2012. The percentage representation of gray directors is increasing in India over time (Sarkar, 2009). However, prior studies have not explored their influence on corporate boards' functioning. Nor have they investigated the nature and degree of control that gray directors exercise over the functioning of corporate boards. Table II presents a summary of the findings of prior research on gray directors.

\begin{tabular}{lll} 
Whether independent or not & Executive & Whether executive or non-executive \\
\hline Independent & 1. na & 2. Objective outsider \\
Non-independent & 3. Benevolent insider & 4. Gray directors
\end{tabular}

Gray directors and executive compensation

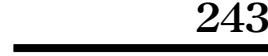


EJMBE 28,3

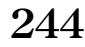

Themes Country Sample Findings

Association between gray directors and firm value/performance

Choi et al. (2007) South Korea 457 Gray directors exercise an insignificant effect on firm performance Yammeesri and Thailand 245 Presence of gray directors is not a significant determinant of firm Herath (2010) value

Zakaria et al. (2010) Malaysia 277 There is an inverse relationship between the performance of firms and the number of gray directors

Kumar and India

Singh (2012)

Khan et al. (2012) Australia

157 The proportion of gray directors is negatively associated with firm value

188 There is no statistically significant association between firm's performance and the proportion of gray directors on corporate boards

Srivastava (2015) India

164 Presence of gray directors is negatively associated with firm's financial performance

Association between gray directors, board composition and corporate governance

Core et al. (1999) USA

495 There is a negative relationship between the presence of gray directors on corporate boards and standards of corporate governance. Accordingly, reduction in standards of corporate governance is associated with the presence of gray directors on corporate boards

$\begin{array}{lc}\begin{array}{l}\text { Shivdasani and } \\ \text { Yermack (1999) } \\ \text { Carcello and }\end{array} & \text { USA } \\ \begin{array}{l}\text { Neal (2000) } \\ \text { Raghunandan } \\ \text { et al. (2001) } \\ \text { Clifford and Evans } \\ \text { (2002) }\end{array} & \text { USA } \\ \begin{array}{l}\text { Ryan and } \\ \text { Wiggins (2004) }\end{array} & \text { USA } \\ \begin{array}{l}\text { Sarkar (2009) } \\ \text { India }\end{array} \\ \begin{array}{l}\text { Osi (2009) } \\ \text { Borokhovich } \\ \text { et al. (2014) }\end{array} & \text { USA } \\ \text { Sarpal (2015) } & \text { India }\end{array}$

341 The degree of involvement of CEOs is found to be high in the process of appointment of gray directors

223 There is a negative association between the proportion of gray directors and receipt of going concern report

The audit committee is likely to perform better in the absence of gray directors than with their presence

47 Findings revealed that 35 percent of non-executive directors were gray directors. The combination of insider and gray directors constituted a majority of corporate boards

1,018 Independent directors on the board dominated by inside and gray directors are less incentivized to monitor

186 The proportion of gray directors in India increased during the study period

Presence of gray directors may diminish the integrity of the board

370 Gray directors place their interests as shareholders first when a replacement decision is likely to weaken their business ties with the firm

114 CEO duality improves the level of board independence by limiting the proportion of gray directors on the board

Association between gray directors, earnings management and corporate fraud

Beasley (1996) USA

150 The negative association between the likelihood of fraud and the percentage of gray directors

He et al. (2009) Australia

231 Positive association between earnings management and share ownership of gray directors

Hsu and Wu (2014) UK

Table II.

Summary of research findings on

Houston et al. USA

(2016)

158 The higher the number of gray directors on the board, the lower would be the probability of corporate failure

339 There is likely to be an increase in corporate fraud when former employees serve as gray directors

Source: Summary of literature review

Prior research reveals several interesting implications of the presence of gray directors on corporate boards. First, there is a strong possibility of a conflict of interest. Such conflict might arise because gray directors are likely to demonstrate their "obligation" to CEOs as their CEO might have taken the initiative in appointing them (Shivdasani and Yermack, 1999). Second, 
this will necessarily lead to a decrease in the standard of corporate governance (Core et al., 1999). Third, the incentive for gray directors to be a part of the monitoring mechanism is almost non-existent (Ryan and Wiggins, 2004). Fourth, gray directors are likely to act in their capacity as shareholders rather than as representatives of other shareholders especially in those circumstances in which their self-interest is at stake (Borokhovich et al., 2014). Fifth, the extent of board independence is likely to increase if there is a reduction in the proportion of gray directors on boards (Sarpal, 2015). Sixth, corporate fraud is probable (Houston et al., 2016) in the presence of gray directors though the evidence on the same remains mixed (Beasley, 1996). Seventh, the tendency to engage in practices related to earnings management would increase if the proportion of shareholdings of gray directors is on the rise (He et al., 2009). At last, there is overwhelming evidence to show that the presence of gray directors on corporate boards does not increase corporate value or financial performance (Choi et al., 2007).

Despite the presence of compelling evidence against the utility of gray directors in maximizing corporate value, the proportion of gray directors has nevertheless increased the world over (Clifford and Evans, 2002).Therefore, it is theoretically useful to understand the underpinnings of this phenomenon. Earlier, we pointed out that we cannot understand the implications of gray directors without using agency theory or stewardship theory. While recognizing this, it is also imperative to look for other specific theories for a precise understanding of the underlying process that builds linkages between gray directors and excessive CEO compensation. Knowing these interlinkages would also help us to appreciate how this relationship becomes operational, specifically in those firms that have a dominant presence of controlling shareholders who owe their appointment on corporate boards especially in family controlled firms.

There are intellectually illuminating narratives that explain the phenomenon of executive compensation. Scholars have grouped these theories in terms of their focus. Accordingly, there are three approaches with which we can classify prior research on compensation. These are the agency approach, value approach and symbolic approach (Otten, 2007).

Under the agency approach fall complete contract theory, prospect theory, managerial theory, and, class hegemony theory (Bebchuk et al., 2002; Fama, 1980; Fama and Jensen, 1983; Gomez-Mejia and Wiseman, 1997; Kahneman and Tversky, 1979; Jensen and Meckling, 1976). These theories explain executive compensation even as they address the issues of agency problem and agency costs. These theories aim at "legitimizations of pay levels and structures [...] (that) [...] are based on arguments of market forces and conceptions of executive pay at risk" (Otten, 2007). These theories assume that managers are fundamentally individualistic and rational. Accordingly, these theories articulate that it is self-interest that drives actors. Therefore, the essential argument is that the source of motivation of managers is higher levels of executive compensation. The objective of higher levels of CEO compensation is to incentivize them to act in the interests of shareholders. However, this explanation is limited to its relevance to the issue of monitoring the behavior of executives. Accordingly, these theories do not provide a convincing elucidation of the complicit behavior of gray directors in fixing excessive executive compensation.

Next, the value approach subsumes other theories such as marginal productivity theory, efficiency wage theory, human capital theory, opportunity cost theory and superstar theory (Carpenter et al., 2001; Prendergast, 1999; Roberts, 1956; Rosen, 1981). These theories emphasize how much to pay based on the value brought in by the person receiving the pay. In this regard, Otten (2007) argues that "executive pay is legitimized here by arguing that pay is set by market forces and pay is mainly regarded as the market value of executive services" (p. 6). The value approach to executive compensation does not explain gray directors' propensity to remain as mute spectators even while they sacrifice their designated role which demands exercising their independence on matters related to fixation of executive compensation.

Gray directors and executive compensation 
EJMBE

28,3

246

Finally, under the rubric of the symbolic approach are theories such as tournament theory, figurehead theory, stewardship theory, crowding-out theory, implicit/psychological contract theory, socially enacted proportionality theory and social comparison theory (Baker et al., 2002; Davis et al., 1997; Donaldson and Davis, 1991; Frey, 1997; Kidder and Buchholtz, 2002; Lazear and Rosen, 1981; O'Reilly et al., 1988; Ungson and Steers, 1984). According to Otten (2007), "the legitimizing arguments (of the symbolic approach) are based on social (or socio-economical), constructed beliefs about executive roles and how pay ought to reflect this" (p. 14). These theories of executive pay, which prior research classifies under the symbolic approach, focus on what ought to be paid to executives. We argue that it is possible to explain the complicit behavior of gray directors, from the standpoint of the symbolic approach, during the process of fixing and maintaining unduly high executive compensation in family controlled domestic firms in India.

We can invoke the symbolic approach (or more particularly psychological contract theory) to understand the relationship between gray directors and executive compensation through two strands of analyses. The first strand of analysis is "negative" in the sense that it helps us understand why the agency and value approaches are not relevant for understanding the behavior of gray directors. The second strand helps us understand why the symbolic approach is more appropriate than the other two approaches. The agency and value approaches consider the impact of market forces as foundational premises based on which determination of executive compensation can be understood. Invoking value and agency approaches to explain the linkages between gray directors and excessive executive compensation is acceptable in those situations that are marked by complete professionalization of corporate management and, consequently, there is indeed a separation of ownership from management in letter and spirit. However, the agency and value approaches both fail to explain in entirety why executive compensation is excessive in the absence of the conditions mentioned above. Though it is possible to explain excessive compensation using both agency and value approaches, they do not provide us with an acceptable explanation to make sense of the complicit behavior of gray directors. Furthermore, these theories become relevant only in the pronounced presence of agency conflict. However, as regards the role of gray directors, the issue of conflict is not between shareholders and managers. It is, in fact, between controlling shareholders and minority shareholders. Therefore, it is not possible to explain the issue of gray directors' complicity in aligning themselves with the executives of family controlled firms from the perspective of agency conflict.

Earlier we discussed how agency theory and stewardship theory direct the board structure in American and Japanese companies, and conversely, how the behavior of board members is explained (at least to a great extent) by these theories in their respective geographies. However, these theories seem to be inadequate to explain the Indian situation, and even more generally, the behavior of gray directors.

Even if agency theory may be used to explain the behaviors of CEOs and other directors including independent directors who are expected to act in the best interests of shareholders, the theory does not provide an adequate explanation of the behavior of gray directors. The irrelevance of the agency theory about gray directors' behavior while fixing executive compensation arises because of two reasons. First, prior research does not classify gray directors as "independent" directors. Therefore, the very nature of the position of gray directors does not inspire them to execute the moral responsibility of exhibiting true "independence" in their conduct. Second, scholars define gray directors as those directors with either existing or potential ties with their firms. This definition implies that they are more likely to act in the interests of their benefactors than in the interests of shareholders.

A similar problem emerges if we attempt to invoke stewardship theory to explain the behavior of gray directors. According to this theory, "principal satisfaction" is more important 
than executive pay as the source of motivation for top management executives. However, this argument becomes untenable in the context of gray directors because their notion of "principal satisfaction" is unlikely to go beyond the satisfaction of their benefactors within the board itself. Accordingly, they may not consider shareholders as their true "principals." It is against this theoretical background that directors in Quadrant 3 are fundamentally different from directors included in Quadrant 4. Therefore, just as agency theory fails to explain the relationship between gray directors and excessive executive compensation, stewardship theory also does not capture the complexity of this relationship. Otten (2007) argues that "Stewardship theory does not provide clear hypotheses about pay levels or pay structures and could, therefore, be questioned as a useful theory to legitimize executive pay" (p. 16). Accordingly, Otten (2007) narrates the viewpoint of Donaldson (1995) while he states that "stewardship theory sees subordinates as collectivists, pro-organizational and trustworthy as opposed to, e.g., agency theory, which assumes subordinates to be individualistic, opportunistic, and self-serving" (p. 16). Thus, stewardship theory articulates that executives are supposed to take their decisions in the interests of their "principal." From this point of view, excessive executive compensation does not act as the source of executive motivation. Given these propositions of stewardship theory, it also fails to account for the complicit behavior of gray directors in fixing excessive executive compensation.

How do we make sense of the adverse role of "gray" directors in executive compensation? To address this question, we argue that psychological contract theory (within the overall rubric of the symbolic approach) provides us with a credible grasp of the complicit behavior of gray directors that makes them give their silent acceptance to excessive executive compensation. Otten (2007) states that a "psychological contract is an individual's personal set of reciprocal expectations of his obligations and entitlements which do not necessarily have to be mutually agreed upon between the contractors" (p. 17). Accordingly, it is reasonable to argue that gray directors make their attempts to display reciprocity in their behavior while fixing executive compensation. Therefore, in the absence of mutually agreed upon obligations and entitlements, they act in the interests of executives whom they consider as their de facto principals. Accordingly, the need to demonstrate reciprocity in the relationship makes them accord their silent acceptance to decisions on executive compensation. Therefore, it becomes a matter of reciprocal exchange that they need to recognize.

Against this background, it is interesting to note the argument of Rousseau (1998) that there are two foundational features of psychological contracts that operate in such a manner that one party feels obligated to the other party and, accordingly, acts by the expectations of the other party. First, perceived mutual obligations play a critical role in making one party behave according to the expectations of the other even while those expectations are unwritten and they are only perceptual (Rousseau, 1998). These perceived mutual obligations create perceptions regarding reliance losses and, therefore, benefitted actors would strive to maintain the status quo in their relationship equations with their benefactors. Accordingly, beneficiaries of a psychological contract try to live up to the expectations of their benefactors even in those situations wherein organizational change is inevitable. Therefore, we argue that any corporate board functioning process, which bases itself on rewards and incentives, fails to account for the complicit behavior of gray directors.

Second, Rousseau (1998) argues that agency theory oversimplifies the "incentive contract" that exists between an organization and its workers. Employees do not necessarily attribute to their organization the incentives that they receive. Accordingly, they need not endow their organization with the position of "giver" of incentives in their perceptual mindspace. Instead, they might accord the status of benefactor to their immediate supervisor or someone else whom they believe to be their benefactor.

In line with the above arguments, we argue that the phenomenon of psychological contracts adequately explains the relationship between gray directors and excessive 
EJMBE

28,3

248

CEO/executive compensation. The notion of psychological contracts helps provide us with an explanation for the complicit behavior of gray directors because these directors are likely to perceive mutual obligations toward their CEO, whom they might believe to be their benefactor. Therefore, they are more likely to identify themselves with the CEO than with their company or shareholders. This person-based identification, facilitated by a psychological contract between gray directors and their CEO, is likely to make gray directors behave differently from independent directors. As a result, gray directors are expected to be favorable to the CEO of their company while fixing executive compensation. Drawing on psychological contract theory, therefore, we argue that gray directors' implicit psychological contracts with their CEOs will likely to make them feel that their silent acceptance of the proposed executive compensation is a form of reciprocity that they need to demonstrate for being the beneficiaries of their position on the corporate board.

\section{Hypotheses development}

\section{Gray directors and executive compensation}

There are various viewpoints regarding the payment of compensation to executives. As pointed out by many scholars such as Bebchuk et al. (2010), speculative and excessive executive compensation would exercise a negative impact on the process of compliance with standards of corporate governance. Therefore, fixation of excessive executive compensation promotes various forms of misadventures relating to corporate governance on account of agency problems. Accordingly, it has also been argued in the literature that the issue of the debate should not be on how much executive compensation is paid (Jensen and Murphy, 1990a). Instead, it should be on how it is paid especially about the legitimacy of the process of fixation of CEO compensation (Jensen and Murphy, 1990a). However, this is not to deny the importance of paying adequate compensation to top executives for the talent that they bring and the risks that they assume.

Though the individual profiles of directors on boards (independent, affiliated or controlling shareholder) match firms' ownership (institutional, corporate parent and family entrepreneur control) configurations (Sur et al., 2013), it is nevertheless relevant to study implications of the presence of gray directors. This is because the presence of gray directors has been on the rise, especially on the boards of Indian companies. This is intriguing because it raises the question of why this is the case. One reason to seek answers to this question is that companies often mask the presence of gray directors by projecting them as independent directors, though their "independence" is suspected. Therefore, it is reasonable to propose that this might become disadvantageous to minority shareholders. In this connection, it is noteworthy that there is no evidence to show that gray directors provide assistance either in executing a control function (the USA model) or in delivering an expertise function (the Japanese model).

If members of a corporate board owe their position on the board due to either their controlling stake or their ability to offer some functional or strategic expertise, the presence of gray directors becomes problematic. This problem may be further compounded by the relationship between a firm's ownership and board composition. If a firm's ownership lies predominantly with a few controlling shareholders who might have been instrumental in appointing gray directors, the phenomenon of psychological contracts is bound to exercise its impact on gray directors. Accordingly, this is likely to encourage gray directors to behave as if they were the beneficiaries in their relationship with their CEO or top management executives. Thus, there is also a point of concern here about which a word of caution is due. Besides not contributing to firm performance and firm value, the presence of gray directors is also found to be positively associated with earnings management and corporate fraud (He et al., 2009; Houston et al., 2017). It is clear that there are no justifiable theoretical underpinnings behind the presence of gray 
directors. It is not naïve, therefore, to suspect that this could be a case of cronyism as it is not possible to justify the purpose of the selection of gray directors with compelling arguments. Furthermore, it is quite probable that gray directors might only be reciprocating their appointment as a matter of social exchange that they wish to make because of the implicit psychological contract with the CEO and a few other top management executives of their company. Therefore, we argue that the presence of gray directors would be associated with executive compensation and this phenomenon occurs more in family controlled firms than in other categories of firms:

Gray directors and executive compensation

H1a. The proportion of influence of gray directors on the board is positively associated with executive compensation.

H1b. The proportion of influence of gray directors on executive compensation is higher in family controlled firms than in other categories of firms.

\section{Controlling shareholder duality and executive compensation}

As observed by Berle and Means (1932), the distribution of capital among a significantly high number of shareholders allows greater freedom to managers in the use of enterprise resources in publicly traded companies. However, this might lead to agency conflict over the allocation and distribution of corporate resources (Jensen and Meckling, 1976). Furthermore, the information asymmetry that exists between managers and shareholders, which creates a moral hazard problem, does not enable shareholders to verify whether the actual performance of a firm is due to luck or hard work (Rose, 2005). Against this background, the pay-for-performance theory suggests that CEO pay should be fixed to incentivize CEOs for their hard work (Bebchuk, 2005).

In terms of publicly traded large firms wherein a controlling shareholder himself/herself occupies the position of CEO, a situation which we term the controlling shareholder duality, conflict of interest is apparent. Controlling shareholder duality would lead to unfavorable consequences. For instance, fixing one's compensation would expropriate what is otherwise legitimately due to minority shareholders. Expropriation of resources that belong to minority shareholders is known as "tunneling." It manifests itself among CEOs in the form of fixing their compensation (Cheung et al., 2005). This process of "tunneling" is likely to be supported by gray directors too. In this regard, Holderness and Sheehan (1988) provide evidence regarding managers, who are majority shareholders in publicly held corporations, having received marginally higher salaries than others. Similar research findings support this phenomenon in other settings (Jiang, 2011; Mangel and Singh, 1993; Mehran, 1995; Ozkan, 2011).

In contrast, scholars have argued that majority shareholders negatively influence the compensation of professional CEOs, and minority shareholders influence the same positively (Abraham and Singh, 2016). As a result, there would be a conflict between the majority and minority shareholders when the compensation of the controlling shareholder$\mathrm{CEO}$ is higher than that of a professional CEO in the same position. Those CEOs who belong to the controlling shareholders' group may also influence the remuneration committee that fixes the CEO's compensation (Jaiswall and Frith, 2009). Jaiswall and Bhattacharya (2016) conclude that the ownership characteristics of Indian private sector firms are positively related to ownership structure. The relationship between ownership characteristics and ownership structure would result in lowering the standards of corporate governance of the firm. Thus, we arrive at the following hypothesis:

H2a. CEOs who are controlling shareholders receive higher pay than professional CEOs.

$H 2 b$. CEO pay in family controlled firms with dominant controlling shareholders is higher than CEO pay in firms of other categories. 
EIMBE

28,3

\section{Constructs}

\section{CEO compensation}

We define CEOs to be those who have the designation of being not only the CEO of their respective companies but also executive directors who may have designations such as those of executive chairman, managing director or joint managing directors. CEO is not a commonly used title of designation for the executive head of companies in India. CEO compensation, for this study, is the aggregate of salary, bonus and perquisites paid to the executive head.

\section{Gray directors}

We define gray directors as those non-executive directors who do not qualify as independent directors.

\section{Family controlled firms}

Family controlled firms are divided into two categories. First, where the dominant shareholder owns the majority of the shares, i.e., Indian individuals or families hold more than 50 percent of shares of the respective companies. Second, where the dominant shareholder owns more than 25 percent but less than 50 percent of shares of their respective companies.

\section{Other categories of firms}

This includes firms where the majority of the shares are owned by the state (government/ public sector undertakings (PSUs)), the majority of shares are held by foreign individuals/ institutions (FORGN) and Indian firms where no individuals/institutions own more than 25 percent of the shares.

\section{Controlling shareholder duality}

Controlling shareholder duality exists when the CEO of the firm is the controlling shareholder, or he/she belongs to the family that possesses a controlling stake in shares of the respective company.

\section{Control variables}

We controlled for CEO duality, profitability, firm size (FS), board size (BS), growth opportunities and risk. The pay-for-performance theory is interlinked with traditional agency theory, which states that executives should work toward maximizing the value of their firm and shareholders. If this were true, we would expect that the level of pay is an increasing function of firm performance (Jensen and Murphy, 1990b; Veliyath and Ramaswamy, 2000). Hence, we controlled for profitability.

We also controlled for other factors based on prior research. For example, Mehran (1995) points out that FS is generally found to be positively related to CEO compensation. Hence, we considered FS as a control variable. We also controlled for BS as it was found to have a positive association with executive compensation. Scholars have argued that large boards are less effective at monitoring (Core et al., 1999) corporate affairs. A lower degree of monitoring will increase the power of CEOs on the board. The trade-off between the degree of monitoring and power of CEOs emerges because inside directors are expected to be loyal to their CEO (Pfeffer, 1981). Hence, we argue that bigger boards may lead to higher compensation. However, prior studies have documented a non-linear relationship between BS and CEO compensation (Agoraki et al., 2010; Yeung, 2018). The non-linear relationship between BS and CEO compensation implies that BS demonstrates a positive association with CEO pay up to a point beyond which this relationship is expected to become negative. Increase in BS, beyond a point, is likely to bring in diverse and independent opinions. Hence, BS may exercise a constraining effect on the magnitude of CEO pay. Therefore, we include the square of BS as a control variable to control for this potentially non-linear effect. 
Furthermore, previous studies have also established a positive association between CEO being the chairman of the board, i.e., "CEO Duality" and executive compensation (Dorata and Petra, 2008; Tien et al., 2013). Hence, we include CEO Duality as a control variable. Furthermore, prior research argues that firms with higher growth opportunities would have businesses which are complex to manage. Therefore, CEO compensation may be higher in those firms which have higher growth opportunities (Core et al., 2003). Consistent with prior research, we use the price-to-book ratio as a proxy for capturing growth opportunity (Li and Kuo, 2017).

Gray directors and executive compensation

\section{Sample and methodology}

\section{Sample}

We divide publicly traded firms into five categories based on their shareholding pattern. This categorization is partially derived from how corporate ownership is classified by Balasubramanian et al. (2013):

(1) family controlled firm - dominant shareholding (FC-1): Indian firms with controlling shareholder(s) who own more than 50 percent of shares;

(2) family controlled firms - non-dominant shareholding (FC-2): Indian firms in which the shareholding of the controlling shareholders is between 25 and 50 percent;

(3) PSUs: promoted by the central/state government with their shareholding being more than 50 percent;

(4) firms controlled by foreign controlling shareholders (FORGN): firms listed in India with a foreign controlling shareholder who owns more than 50 percent of shares; and

(5) MCF: Indian firms in which nobody owns shares more than 25 percent.

The sample herein consists of 438 publicly traded firms listed in the NIFTY 500 index of the National Stock Exchange (NSE), which constitutes over 95 percent of the free float market capitalization. This sample covers all five categories of firms delineated above. The Nifty 500 is a broad-based index and an appropriate sample that adequately represents publicly traded Indian firms. We have drawn sample firms from 11 industries (GICS classification), i.e., communication services, consumer discretionary, consumer staples, energy, financials, health care, industrials, information technology, materials, real estate and utilities. The NIFTY 500 index comprises 501 listed companies. We considered Tata Motors Ltd (ordinary shares) and Tata Motors Ltd (DVR) as a single firm. Accordingly, the number of sample firms would come down to 500 firms. Next, we eliminated 18 firms which were listed after March 2013 as the data for these firms were not available for a full period of five years. Furthermore, the CEO compensation data for 44 companies were either unreported or unavailable for a full period of five years. We excluded these companies from further inquiry. Hence why the final sample size comprised of 438 publicly traded firms. Table III reports the sample firms based on ownership categories.

We collected data on board structure and compensation from the Indian Board Database (NSEINFOBASE), which provides details about directors of the companies listed in NSE. The Indian Board database provides the details such as the names of directors, designation, whether the directors are independent or not, whether the director/CEO belongs to the controlling shareholder's group, and the presence of CEO duality. This information is not available in other databases that provide information on Indian boards. We collected data such as profits and total assets from Ace Equity database. Data on price-to-book ratio and Bloomberg one-year default probability were retrieved from the Bloomberg database. All data for all sample firms span March 2013 to March 2017. While the majority of the firms followed April to March as the financial year, a few of them followed the calendar year (January to December) as their financial year. 
EJMBE

28,3

\section{2}

Table III.

Ownership categories of the sample firms
Ownership categories

Family controlled firms - FC-1

Family controlled firms - FC-2

Public sector enterprises - PSU

Firms controlled by foreign controlling shareholders (FORGN)

Management-controlled firms - MCF

Total

\begin{tabular}{crrr}
$\begin{array}{c}\text { Number of } \\
\text { firms in } \\
\text { NIFTY 500 }\end{array}$ & \multicolumn{3}{c}{$\begin{array}{c}\text { Number of } \\
\text { firms in } \\
\text { the sample }\end{array}$} \\
\hline 185 & 37.00 & 161 & 36.76 \\
159 & 31.60 & 138 & 31.51 \\
55 & 11.00 & 48 & 10.96 \\
54 & 10.80 & 50 & 11.42 \\
48 & 9.60 & 41 & 9.36 \\
501 & 100.00 & 438 & 100.00
\end{tabular}

Note: NIFTY 500 index comprised of 501 firms. The differential voting rights (DVR) shares issued by a firm were also included in the Index

\section{Model}

The relationship between CEO compensation, gray directors, ownership structure and control variables (Model 1) is tested using the following equation with variable definitions provided in Table IV:

$$
\begin{aligned}
\ln (\mathrm{CEO} \text { pay })= & \beta_{0}+\beta_{1} \mathrm{PROPGD}+B_{2} \mathrm{CSDUAL}+\beta_{3} \mathrm{FC}-2+\beta_{4} \mathrm{PSU}+\beta_{5} \mathrm{FORGN} \\
& +\beta_{6} \mathrm{MCF}+B_{7} \mathrm{CEODUAL}+\beta_{8} \mathrm{PFT}+\beta_{9} \mathrm{SIZE}+\beta_{10} \mathrm{BS}+\beta_{11} \mathrm{BS}^{2} \\
& +\beta_{12} \mathrm{PTB}+\beta_{13} \mathrm{DRSK}+\text { YearEffect }+ \text { IndustryEffect }+e_{t} .
\end{aligned}
$$

\begin{tabular}{|c|c|}
\hline Variables & Measurements of variables \\
\hline \multicolumn{2}{|l|}{ Ownership variables } \\
\hline $\begin{array}{l}\text { Family controlled firms - dominant controlling } \\
\text { shareholder (FC-1) }\end{array}$ & $\begin{array}{l}\text { A dummy variable takes } 1 \text { if a controlling shareholder } \\
\text { owns } 50 \text { percent or more of the shares, } 0 \text { otherwise }\end{array}$ \\
\hline $\begin{array}{l}\text { Family controlled firms - non-dominant } \\
\text { controlling shareholder (FC-2) }\end{array}$ & $\begin{array}{l}\text { A dummy variable takes } 1 \text { if a controlling shareholder } \\
\text { owns } 25-50 \text { percent of the shares, } 0 \text { otherwise }\end{array}$ \\
\hline Government/public sector undertakings (PSUs) & $\begin{array}{l}\text { A dummy variable takes } 1 \text { if the controlling shareholder } \\
\text { is central or state government, } 0 \text { otherwise }\end{array}$ \\
\hline $\begin{array}{l}\text { Firms controlled by foreign controlling } \\
\text { shareholders (FORGN) }\end{array}$ & $\begin{array}{l}\text { A dummy variable takes } 1 \text { if a foreign controlling } \\
\text { shareholder owns } 50 \text { percent or more shares, } 0 \text { otherwise }\end{array}$ \\
\hline Management-controlled firms (MCF) & $\begin{array}{l}\text { A dummy variable takes } 1 \text { if the controlling } \\
\text { shareholders holding is less than } 25 \text { percent, } 0 \text { otherwise }\end{array}$ \\
\hline Controlling shareholder duality & $\begin{array}{l}\text { A dummy variable takes } 1 \text { if the CEO belongs to the } \\
\text { controlling shareholders group, } 0 \text { otherwise }\end{array}$ \\
\hline
\end{tabular}

Board structure variables

The proportion of gray directors (PROPGD)

CEO duality (CEODUAL)

Board size (BS)

Board size squared $\left(\mathrm{BS}^{2}\right)$

Other variables

Profitability (PFT)

Table IV.

Description of variables and their measurements
Firm size (SIZE)

Price-to-book ratio (PTB)

Risk (DRSK)

Note: The table reports the operational definitions of all independent variables Log of total assets
Computed by dividing the number of gray directors by the total number of directors

A dummy variable takes 1 if the $\mathrm{CEO}$ is chairman of the board, 0 otherwise

The number of directors on the board

Square of board size to test for potential non-linearity

A dummy variable takes 1 if $\mathrm{ROE}$ is positive, 0 otherwise

Market price per share divided by book value per share Bloomberg one-year default probability 
To control for changes in variables, which may be due to time and industry-specific factors, we included year and industry dummies in the model. By doing this, we also controlled for the presence of serial correlation in the panel data (Basuroy et al., 2014). We checked the data for the presence of outliers that could affect the predictive power of the results. For this purpose, we performed the Grubbs test (also known as the maximum normed residual test). The results indicate that there are no incoherent values in any variables.

To examine the association between the presence of gray directors and CEO pay based on ownership category, we split the sample into five ownership categories listed above. Splitting the sample is consistent with the method adopted in earlier studies (Raithatha and Komera, 2016; Saravanan et al., 2017). In the following equation (Models 2 and 3), we consider the presence of gray directors (PROPGD), controlling shareholder duality (CSDUAL), CEO duality (CEODUAL), FS, profitability (ROE), BS, growth opportunities (PTB) and risk (DRSK) on CEOs of family controlled firms (FC-1 and FC-2):

$$
\begin{aligned}
\mathrm{Ln}(\mathrm{CEOPay})= & \beta_{0}+\beta_{1} \mathrm{PROPGD}+B_{2} \mathrm{CSDUAL}+B_{3} \mathrm{CEODUAL}+\beta_{4} \mathrm{PFT} \\
& +\beta_{5} \mathrm{SIZE}+\beta_{6} \mathrm{BS}+\beta_{7} \mathrm{BS}^{2}+\beta_{8} \mathrm{PTB}+\beta_{9} \mathrm{DRSK} \\
& + \text { YearEffect }+ \text { IndustryEffect }+e_{t} .
\end{aligned}
$$

In the following equation (Models 4-6), we test the relationship among variables such as gray directors, CEO duality, FS and profitability on CEOs' pay of the other three ownership categories (PSUs, FORGN and MCF):

$$
\begin{aligned}
\operatorname{Ln}(\mathrm{CEO} \text { pay })= & \beta_{0}+\beta_{1} \mathrm{PROPGD}+B_{2} \mathrm{CEODUAL}+\beta_{3} \mathrm{PFT}+\beta_{4} \mathrm{SIZE}+\beta_{5} \mathrm{BS}+\beta_{6} \mathrm{BS}^{2} \\
& +\beta_{7} \mathrm{PTB}+\beta_{8} \mathrm{DRSK}+\text { YearEffect }+ \text { IndustryEffect }+e_{t} .
\end{aligned}
$$

We estimated Equations (1)-(3) on our pooled time-series data using generalized least squares (GLS) random effects models with robust standard errors, thus mitigating against omitted variables bias, autocorrelation and heteroscedasticity. GLS random effects models have been used to examine CEO compensation in prior studies (Combs et al., 2010; Grasse et al., 2014).

\section{Results and discussion}

Table $\mathrm{V}$ presents trends relating to executive compensation in terms of mean, median, maximum and minimum summary statistics of the independent and dependent variables. The average remuneration paid to CEOs is Rs $9.75 \mathrm{~m}$ with Rs $898.88 \mathrm{~m}$ being the maximum. The maximum proportion of gray directors is 0.78 , which violates Clause 49 of the listing agreement of having at least 30 percent (50 percent) independent directors on the board when the chairman is independent (non-independent). We observe this violation mainly in PSUs. They report this information in their Corporate Governance Reports. For instance, in the case of Indian Oil Corporation Ltd, the 2014-2015 report states as follows: "The company does not have the requisite number of independent directors on its board required under the provisions of Section 149 (4) of the Act (Companies Act of 2013) and revised clause 49 of the Equity Listing Agreement." Kaur and Gill (2008) made similar observations about PSUs. This non-compliance is due to conflicts in the law that governs PSUs. Beyond PSUs, all other firms were found to be compliant with Clause 49 of the listing agreement.

The mean of absolute total assets was Rs35.95bn with a minimum of Rs0.0481bn and a maximum of Rs2,973bn. For statistical purposes, we have taken the natural logarithm of total assets to address the issue of heteroscedasticity (Ramaswamy et al., 2000). Controlling shareholder duality (CSDUAL) is commonly found in family controlled firms in India. Similarly, playing dual roles of being a $\mathrm{CEO}$ and chairman of the board is also found in 


\begin{tabular}{|c|c|c|c|c|c|c|}
\hline \multirow{2}{*}{$\begin{array}{l}\text { EJMBE } \\
28,3\end{array}$} & \\
\hline & Variable & Obs. & Mean & SD & Min. & Max. \\
\hline \multirow{6}{*}{254} & $\ln (\mathrm{CEOPay})$ & 2,190 & 15.145 & 1.535 & 9.210 & 20.617 \\
\hline & PROPGD & 2,190 & 0.157 & 0.148 & 0.000 & 0.778 \\
\hline & CSDUAL & 2,190 & 0.170 & 0.376 & 0.000 & 1.000 \\
\hline & CEODUAL & 2,190 & 0.423 & 0.494 & 0.000 & 1.000 \\
\hline & FC-1 & 2,190 & 0.368 & 0.482 & 0.000 & 1.000 \\
\hline & $\mathrm{FC}-2$ & 2,190 & 0.315 & 0.465 & 0.000 & 1.000 \\
\hline & PSU & 2,190 & 0.110 & 0.312 & 0.000 & 1.000 \\
\hline & FORGN & 2,190 & 0.114 & 0.318 & 0.000 & 1.000 \\
\hline & $\mathrm{MCF}$ & 2,190 & 0.094 & 0.291 & 0.000 & 1.000 \\
\hline & SIZE & 2,190 & 22.407 & 1.700 & 15.386 & 28.721 \\
\hline & ROE & 2,190 & 14.715 & 14.863 & -47.100 & 124.250 \\
\hline & BS & 2,190 & 10.859 & 2.614 & 2.000 & 23.000 \\
\hline & $\mathrm{BS}^{2}$ & 2,190 & 124.748 & 62.178 & 4.000 & 529.000 \\
\hline & PTB & 2,190 & 4.035 & 7.765 & 0.047 & 251.148 \\
\hline & DRSK & 2,190 & 0.003 & 0.011 & 0.000 & 0.370 \\
\hline $\begin{array}{l}\text { Table V. } \\
\text { Summary statistics }\end{array}$ & \multicolumn{6}{|c|}{$\begin{array}{l}\text { Notes: In(CEO pay) is the natural logarithm of CEO compensation defined as the sum of salary, perquisites, } \\
\text { commission, sitting fees and bonuses. PROPGD is the proportion of gray directors on the board. CSDUAL is } \\
\text { controlling shareholder duality. CEODUAL is CEO duality. FC-1 is family controlled firms with a dominant } \\
\text { controlling shareholder. FC-2 is family controlled firms with a non-dominant controlling shareholder. PSU is } \\
\text { public sector undertaking with majority shareholding by the government. FORGN is firms with a foreign } \\
\text { controlling shareholder and MCF is management-controlled firms wherein shares are held severally. ROE is } \\
\text { return on equity, defined as income after tax and extraordinary items divided by average total shareholders' } \\
\text { funds. SIZE is firm size measured by the natural logarithm of total assets. BS is board size. BS }{ }^{2} \text { is the square } \\
\text { of board size. PTB is the market price per share divided by the book value per share. DRSK is one-year } \\
\text { Bloomberg default risk }\end{array}$} \\
\hline
\end{tabular}

many corporate cases. The average BS is 10.86 with the maximum number being 23 directors on the board of Larsen and Toubro Ltd.

Table VI presents a correlation matrix. CEO pay, represented by its natural logarithm, is positively correlated with the following independent variables: controlling shareholder duality (CSDUAL), family controlled firms with both dominant and non-dominant shareholding by controlling shareholders (FC-1 and FC-2), firms with a foreign controlling shareholder (FORGN) and profitability (ROE). Furthermore, CEO pay is negatively correlated with the proportion of gray directors, PSU, firms with dispersed ownership (MCF) and FS (SIZE).

The correlation matrix reveals that multicollinearity is not an issue since the correlation between the independent variables is low. Furthermore, we estimated variance inflation factors (VIFs). The average VIF and individual VIFs are within an acceptable range (1.05-1.82).

Table VII provides estimates from Model 1 wherein the log (of CEO pay) is the dependent variable. The proportion of gray directors (PROPGD) is found to be positively related to CEO pay. It is found to be statistically significant as hypothesized, at the 5 percent level. Results of this study thus lend support to the proposition that as the number of gray directors on corporate boards increases, so too does CEOs' pay. Controlling shareholder duality (CSDUAL) is also found to be positively associated with CEOs' pay. In other words, the salary of a CEO, who is also a controlling shareholder or belongs to the controlling shareholder group, is higher than that of a professional CEO. Therefore, we fail to reject H1a. According to Kumar and Singh (2013), controlling shareholders may wield significant influence over the board and management due to their substantial shareholding and voting rights. Therefore, the higher pay for CEOs who are controlling shareholders cannot be justified.

CEOs who are also controlling shareholders (CSDUAL) received higher salaries than professional CEOs. Hence, we fail to reject $H 2 a$. CEOs from founding families or the 


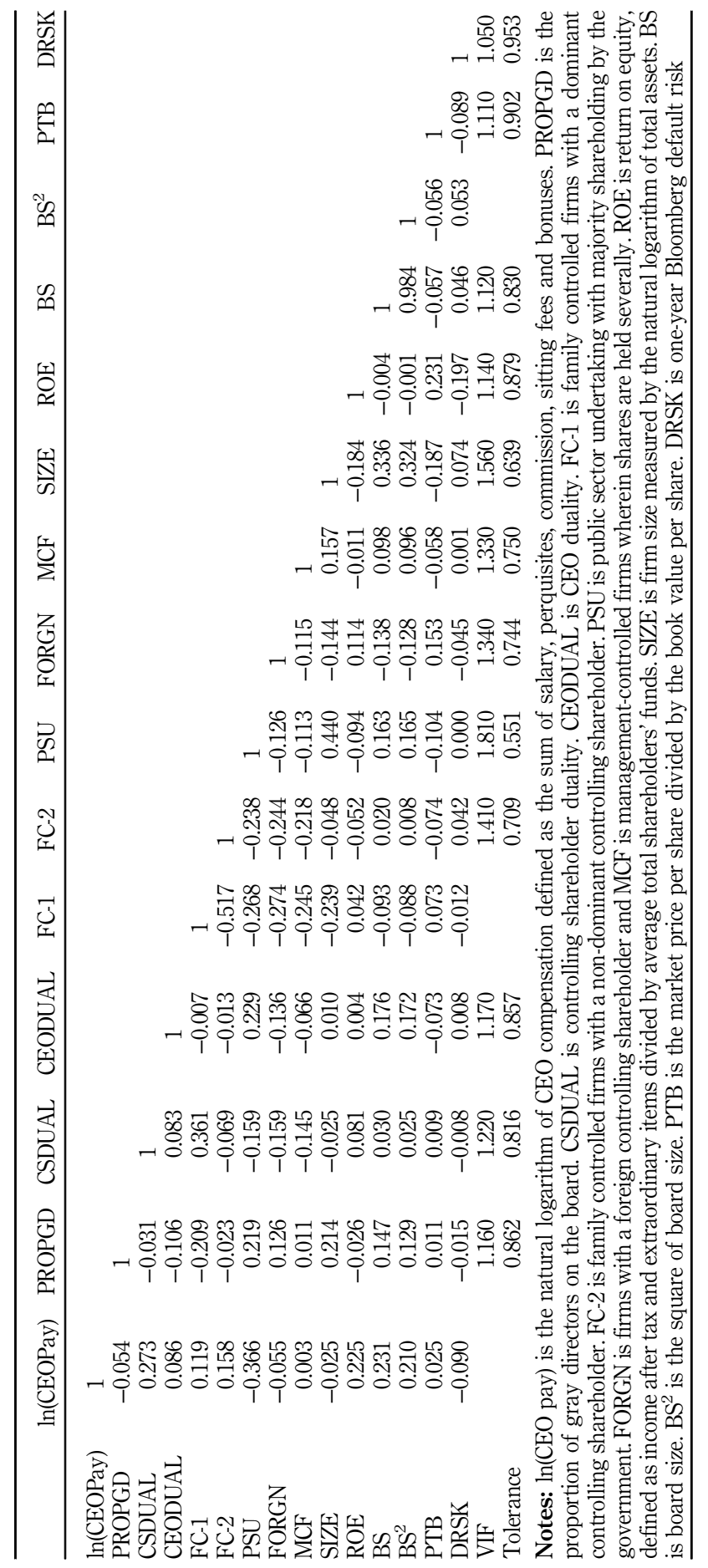

Gray directors and executive compensation

255

Table VI. Correlation matrix 


\section{EJMBE}

28,3

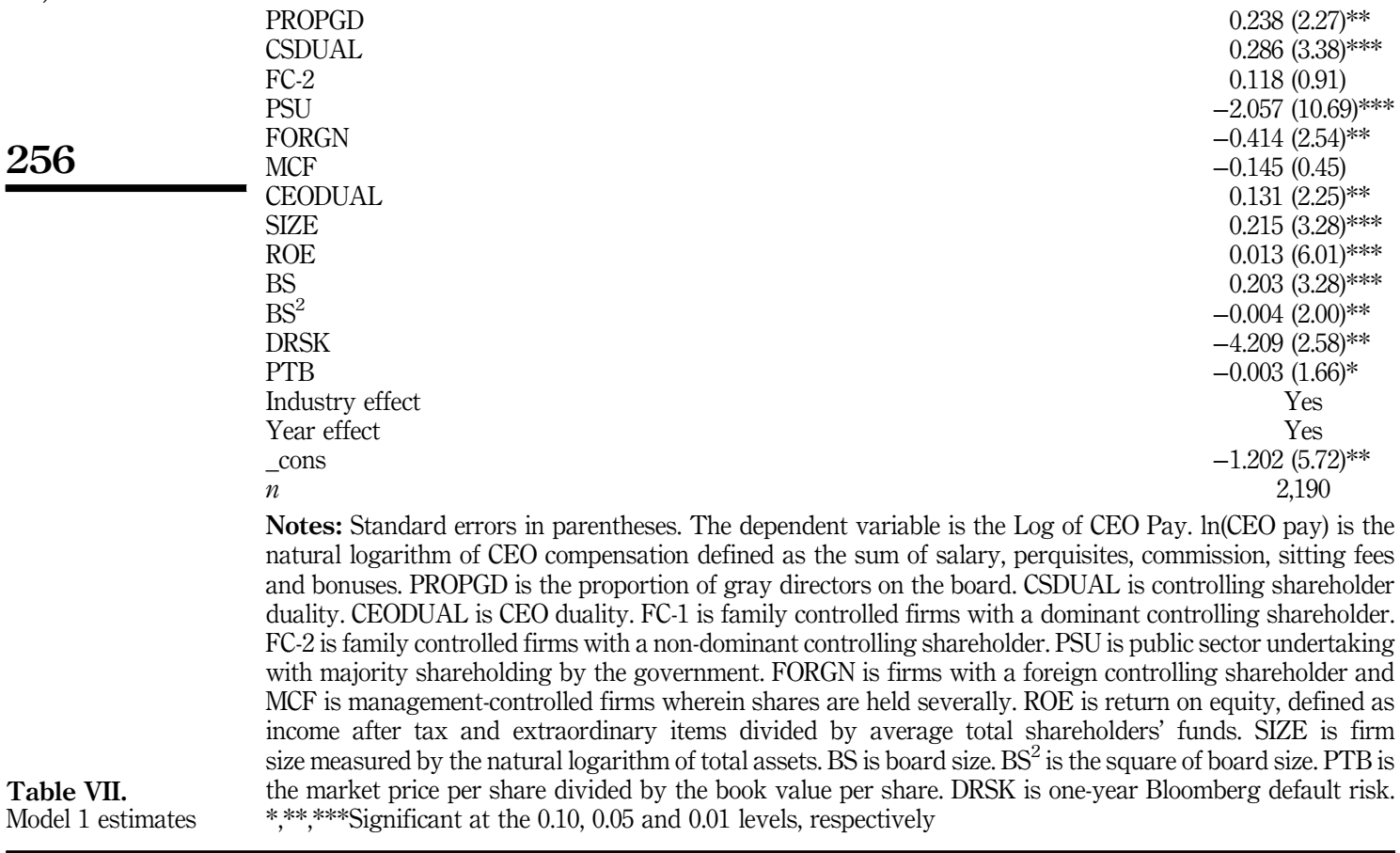

controlling shareholder's group are perceived to wield considerable managerial power in board decisions (Chakrabarti et al., 2012). The combined effect of the presence of gray directors on boards and controlling shareholder duality in fixing CEO compensation might be a matter of concern for minority shareholders.

Ownership structure is found to be a significant determinant of CEO pay in the Indian context. We find that the salary of CEOs of family controlled firms with dominant controlling shareholder (FC-1) is significantly higher than that of CEOs of PSUs and firms controlled by foreign controlling shareholders (FORGN). Hence, we fail to reject $H 2 b$. The CEOs of PSUs received a lower level of compensation. Results of prior research (Ghosh, 2010) also conclude that CEO compensation in state-owned firms is significantly lower than CEO compensation across other ownership groups. Firth et al. (2007) argue that the CEO is more likely to be a bureaucrat and his or her managerial skills may be lower than those of a professional CEO in private firms when the government owns the majority shares in a firm. They further observe that equilibrium wages will be lower in government-owned firms (PSUs) when there is a difference in managerial quality. The relationship between lower wages in government-owned firms and the differences in managerial quality explains the lower compensation for the CEOs of PSUs. CEO compensation in family controlled firms with non-dominant controlling shareholder(s) is higher in comparison with FC-1. However, this relationship is found to be statistically insignificant.

Executive compensation is positively associated with CEO duality (CEODUAL). The positive association between executive compensation and CEO duality implies that when a CEO is chairing the board, the compensation will be higher. Our results support the findings of an earlier study in India (Saravanan et al., 2017). Hence, firms may consider 
separating the positions of CEO and the chairperson of the board (Dorata and Petra, 2008). As hypothesized, the CEOs of larger firms received higher compensation. Also, the results indicate that there is a positive relationship between firm performance and executive compensation. Jaiswall and Frith (2009) and Raithatha and Komera (2016) have also reported similar findings. Based on this, we can conclude that, in general, there is a positive association between compensation and firm performance. We again examine the effect of firm performance on compensation across ownership categories. This analysis will reveal if the positive relationship between pay and performance exists across the ownership categories.

BS is a significant predictor of executive compensation. This is an indication of the possible collusion between the CEO and the board of directors in fixing compensation. However, it is interesting to note that the nature of the relationship between BS and compensation is non-linear. Therefore, we infer that the increase in the size of the board of directors beyond a certain point will reduce CEO pay. These results are consistent Yeung (2018). The relationship between price-to-book ratio and CEO pay, which is a proxy for growth opportunity, is negatively related to CEO pay. The negative association between the price-to-book ratio and CEO pay may be due to the firm's willingness to commit financial resources to growth opportunities. Furthermore, default risk is negatively associated with CEO pay. This indicates that there is no adequate, corresponding reward for the risks that top executives take in their strategic business decisions.

To test the relationship across ownership categories, we estimated the relationship between the variables based on the sample split methodology explained earlier. We divided all the firms into five ownership categories, as described in Table IV. Out of the 438 sample firms, there were 299 family controlled firms, and the remaining 139 firms were from other ownership categories. Table VIII presents the results.

\begin{tabular}{lccccc}
\hline & Model 2 FC-1 & Model 3 FC-2 & Model 4 PSUs & Model 5 FORGN & Model 6 MCF \\
\hline PROPGD & $2.382(6.36)^{* * * *}$ & $0.844(1.72)^{*}$ & $-1.084(2.67)^{* * * *}$ & $-0.410(0.65)$ & $-0.342(0.80)$ \\
CSDUAL & $0.287(2.61)^{* * *}$ & $0.217(1.53)$ & & & \\
CEODUAL & $-0.014(0.17)$ & $0.316(3.08)^{* * *}$ & $0.040(0.17)$ & $0.146(0.77)$ & $0.108(0.79)$ \\
SIZE & $0.123(1.39)$ & $0.267(3.89)^{* * * *}$ & $0.215(2.34)^{* * *}$ & $0.482(3.24)^{* * * *}$ & $0.287(3.61)^{* * *}$ \\
ROE & $0.015(3.57)^{* * * *}$ & $0.011(3.13)^{* * * *}$ & $-0.001(0.03)$ & $0.018(2.87)^{* * *}$ & $0.011(1.46)$ \\
BS & $0.070(0.91)$ & $0.311(1.91)^{*}$ & $0.040(1.35)$ & $0.220(1.10)$ & $0.122(0.76)$ \\
BS & $0.001(0.36)$ & $-0.008(1.28)$ & $-0.006(1.09)$ & $-0.007(0.75)$ & $-0.003(0.60)$ \\
PTB & $-0.003(2.31)^{* *}$ & $0.002(0.13)$ & $0.003(0.21)$ & $-0.012(0.09)$ & $0.069(1.92)^{*}$ \\
DRSK & $-6.857(1.75)^{*}$ & $-2.066(1.54)$ & $-21.101(1.03)$ & $15.605(3.22)^{* * * *}$ & $-43.37(1.43)$ \\
Industry Effect & Yes & Yes & Yes & Yes & Yes \\
Year Effect & Yes & Yes & Yes & Yes & Yes \\
cons & $10.643(5.08)^{* * *}$ & $5.710(3.07)^{* * *}$ & $7.207(2.66)^{* *}$ & $3.629(1.03)$ & $7.602(3.43)^{* * *}$ \\
$n$ & 805 & 690 & 240 & 250 & 205
\end{tabular}

Notes: Standard errors in parentheses. The dependent variable is the Log of CEO Pay. $\ln$ (CEO pay) is the natural logarithm of CEO compensation defined as the sum of salary, perquisites, commission, sitting fees and bonuses. PROPGD is the proportion of gray directors on the board. CSDUAL is controlling shareholder duality. CEODUAL is CEO duality. FC-1 is family controlled firms with a dominant controlling shareholder. FC-2 is family controlled firms with a non-dominant controlling shareholder. PSU is public sector undertaking with majority shareholding by the government. FORGN is firms with a foreign controlling shareholder and $\mathrm{MCF}$ is management-controlled firms wherein shares are held severally. ROE is return on equity, defined as income after tax and extraordinary items divided by average total shareholders' funds. SIZE is firm size measured by the natural logarithm of total assets. BS is board size. BS ${ }^{2}$ is the square of board size. PTB is the market price per share divided by the book value per share. DRSK is one-year Bloomberg default risk. $*, * * * * *$ Significant at the $0.10,0.05$ and 0.01 levels, respectively

Gray directors and executive compensation

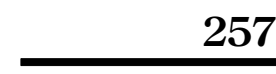


EJMBE

28,3

Estimations of Equations (2) and (3) demonstrate that the association between the proportion of gray directors (PROPGD) and CEO pay increases for family controlled firms (FC-1 and FC-2). These results are also statistically significant. Thus, we fail to reject $H 1 b$. The proportion of gray directors (PROPGD) is negatively associated with the CEO compensation of PSUs, firms with foreign controlling shareholder(s), and MCF. In the case of PSUs, gray directors of PSUs are nominees of government. For example, in BHEL Ltd, we observe that the gray directors are from: the Department of Industrial Policy and Promotion, Ministry of Commerce and Industry; and the Department of Heavy Industry, Ministry of Heavy Industries \& Public Enterprises.

Similarly, in ONGC Ltd, nominee directors were from the Ministry of Petroleum \& Natural Gas. Government is the majority shareholder in PSUs. Therefore, its nominee directors may be considered as the shareholder representatives on the board. In the case of firms controlled by foreign shareholders such as 3M Ltd, or BASF Ltd, we observe the presence of representatives of parent firms on their respective boards. We may consider this as "international overseeing." Gray directors, in firms with dispersed ownership (MCF), represent institutional shareholders who may happen to be the single largest shareholder group. For instance, in Larsen \& Toubro Ltd, non-executive non-independent directors represent equity interest of Life Insurance Corporation of India and Specified Undertaking of Unit Trust of India.

However, in the case of family controlled firms, the role of gray directors leads us to suspect cronyism. Sarpal (2015) and Srivastava (2015) suggest that there is a negative relationship between firm performance and the proportion of gray directors. Whilst there is a negative effect of board structure of family controlled firms on firm performance according to Bhatt and Bhattacharya (2017). Therefore, based on this evidence, the role of gray directors on the respective corporate boards would become questionable. Empirical evidence, provided in this paper, lends support to the implications of psychological contract theory in making sense of the role of gray directors in influencing the magnitude of CEO compensation.

CSDUAL was found to be significantly associated with CEO compensation of family firms wherein controlling shareholders own more than 50 percent of shares (FC-1). CEO duality (CEODUAL) is positively related to the CEO compensation of family controlled firms with non-dominant controlling shareholder(s) (FC-2). This finding is interesting because firms belonging to the FC-2 category may attempt to control the board by holding the dual position of CEO and chairperson. Therefore, we posit that controlling shareholders may exercise their power to pay themselves high compensation (Jaiswall and Frith, 2009).

The relationship between CEO pay and CEO duality is insignificant across other ownership categories. CEO pay increased with FS except in the case of family controlled firms with dominant controlling shareholder(s) (FC-1). BS failed to explain the changes in CEO pay across ownership categories except for the FC-2 ownership category.

Results of this study show that profitability (ROE) exhibits a significant positive association with CEO pay in firms that belong to FC-1, FC-2 and FORGN ownership categories. However, the relationship between profitability and CEO pay is statistically insignificant among firms grouped under PSU and MCF ownership categories. There is no evidence for the presence of a non-linear relationship between CEO pay and BS across ownership categories.

\section{Robustness of results}

We reexamined the models using a two-step dynamic panel data model (Table IX) introducing a lagged dependent variable (Fabbri and Marin, 2012). Dynamic panel estimation addresses the issue of endogeneity. The utility of estimating a dynamic model stems from the fact that it accounts for potential dynamic relationships among variables (Raithatha and Komera, 2016). The outcomes are consistent with the results reported using GLS random effects modeling. 


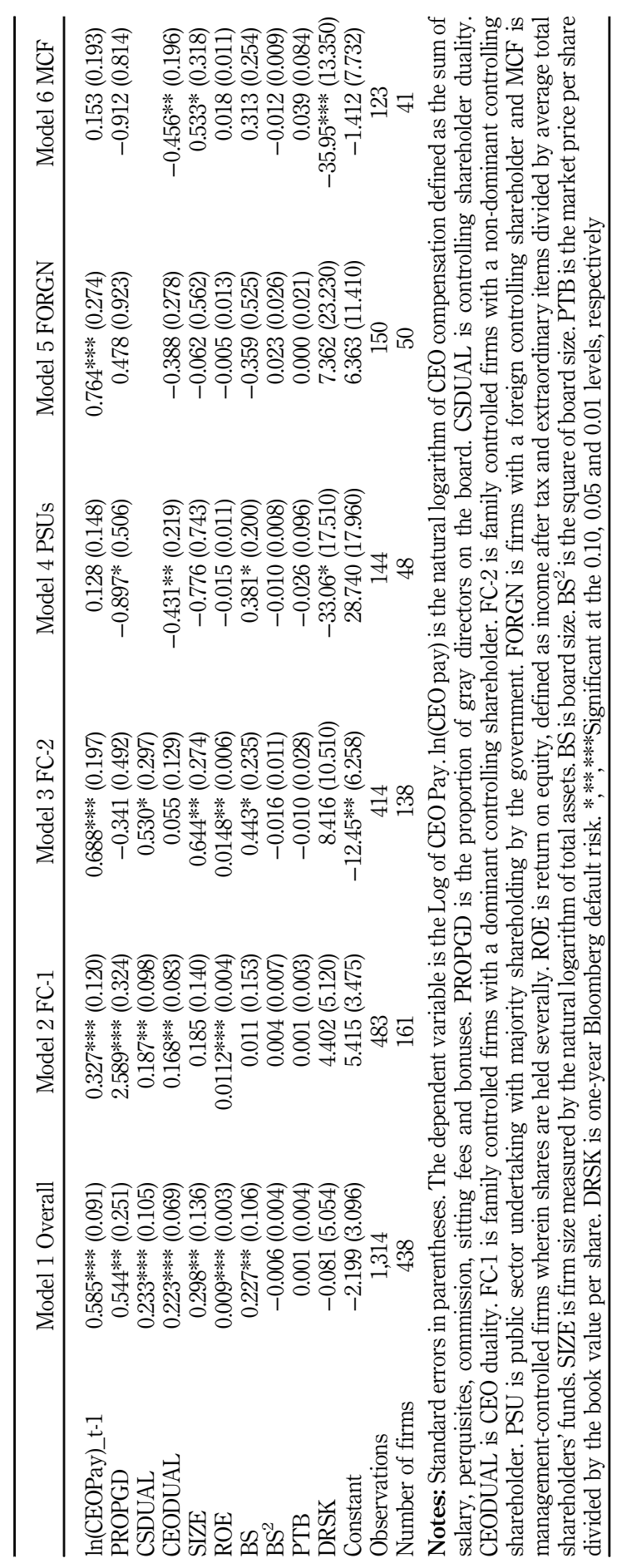

Gray directors and executive compensation

259

Table IX.

Results of dynamic panel estimator 
EIMBE

28,3

The results indicate that past pay has a significant positive association with current CEO pay. Also, the results confirm our hypothesis that the proportion of gray directors (PROPGD) on the board demonstrates a positive and significant association with CEO pay. The effect is positive for family controlled firms and negative for firms controlled by foreign shareholders. Furthermore, the estimation using the dynamic panel model confirms the results presented earlier. For instance, the compensation of the CEO belonging to the controlling shareholder group is higher than that of a professional CEO. The ROE had a significant positive association with the CEO pay among the family controlled firms (FC-1 and FC-2). This result confirms the "pay-for-performance" theory. Thus, the results of the dynamic panel model confirm that our findings are robust and not spurious.

\section{Directions for future research}

Future research may focus on describing the role of gray directors on the board based on ownership categories and investigate the relationship between the presence of gray directors and firm value. It would also be fruitful to explore possible moderators in the relationship between gray directors, firm performance, corporate governance and earnings management.

\section{Conclusion}

We hypothesized that the presence of gray directors would be positively associated with the magnitude of CEO compensation, and the findings reported herein lend support to this. Furthermore, we found that this association changed across ownership categories. The presence of gray directors is found to be associated with higher compensation of CEOs of family controlled firms. However, their presence is found to be associated with decreased CEO compensation in private foreign, PSUs and dispersed ownership firms. Adding to this, we found that the compensation of CEOs who are in the controlling shareholder group is higher than that of professional CEOs.

Furthermore, this paper has situated the relationship between gray directors and CEO pay on the theoretical rationale advanced by psychological contracts theory. We conclude, therefore, that gray directors' complicity in fixing unduly high CEO compensation is a symptom of cronyism. The hybrid board structure that India has adopted, with the desire to bring the best of Anglo Saxon and Japanese board philosophies, should be held responsible for the emergence of a self-serving situation. Therefore, this calls for the exploration of fresh thinking to bring about required changes in the regulatory framework.

\section{Note}

1. A NYSE-listed US company must have a majority of directors meeting the independence requirements under Section 303A of the NYSE-Listed Company Manual.

\section{References}

Abraham, E. and Singh, G. (2016), "Does CEO duality give more influence over executive pay to the majority or minority shareholder? (A survey of Brazil)", Corporate Governance, Vol. 16 No. 1, pp. 96-115.

Agoraki, M.-E.K., Delis, M.D. and Staikouras, P.K. (2010), "The effect of board size and composition on bank efficiency", International Journal of Banking, Accounting and Finance, Vol. 2 No. 4, pp. 357-386, available at: https://doi.org/10.1504/JJBAAF.2010.037155

Anderson, R.C. and Reeb, D.M. (2004), "Board composition: balancing family influence in S\&P 500 firms", Administrative Science Quarterly, Vol. 49 No. 2, pp. 209-237.

Baker, G., Gibbons, R. and Murphy, K.J. (2002), "Relational contracts and the theory of the firm", The Quarterly Journal of Economics, Vol. 117 No. 1, pp. 39-84. 
Balasubramanian, B.N. and Ramaswamy, A. (2013), "Ownership trends in corporate India, 2001-2011: evidence and implications.

Balasubramanian, N., Barua, S.K. and Karthik, D. (2013), "Corporate governance issues in executive compensation: the Indian experience (2008-2012)", Indian Institute of Management, No. 426, Bangaluru.

Basuroy, S., Gleason, K.C. and Kannan, Y.H. (2014), "CEO compensation, customer satisfaction, and firm value", Review of Accounting and Finance, Vol. 13 No. 4, pp. 326-352, available at: https://doi.org/10.11 08/RAF-11-2012-0120

Beasley, M.S. (1996), "An empirical analysis of the relation between the board of director composition and financial statement fraud", The Accounting Review, Vol. 71 No. 4, pp. 443-465.

Bebchuk, L.A. (2005), "Pay without performance: overview of the issues", Journal of Applied Corporate Finance, Vol. 17 No. 4, pp. 8-23.

Bebchuk, L.A., Cohen, A. and Spamann, H. (2010), "The wages of failure: executive compensation at Bear Stearns and Lehman 2000-2008”, Yale Journal of Regulation, Vol. 27 No. 3, pp. 257-282.

Bebchuk, L.A., Fried, J.M. and Walker, D.I. (2002), "Managerial power and rent extraction in the design of executive compensation", The University of Chicago Law Review, Vol. 69 No. 3, pp. 751-846, available at: https://doi.org/10.2307/1600632

Berle, A.A. and Means, G.C. (1932), "Property in transaction, the appearance of the corporate system, the concentration of economic power", The Modern Corporation and Private Property, Macmillan, New York, p. 24, available at: https://doi.org/10.2307/3475545

Bhatt, R.R. and Bhattacharya, S. (2017), "Family firms, board structure and firm performance: evidence from top Indian firms", International Journal of Law and Management, Vol. 59 No. 5, pp. 699-717, available at: https://doi.org/10.1108/IJLMA-02-2016-0013

Borokhovich, K.A., Boulton, T.J., Brunarski, K.R. and Harman, Y.S. (2014), "The incentives of grey directors: evidence from unexpected executive and board chair turnover", Journal of Corporate Finance, Vol. 28, pp. 102-115, available at: https://doi.org/10.1016/j.jcorpfin.2013.11.015

Carcello, J.V. and Neal, T.L. (2000), "Audit committee composition and auditor reporting", The Accounting Review, Vol. 75 No. 4, pp. 453-467, available at: https://doi.org/10.23;08/accr.2000 .75.4.453

Carpenter, M.A., Sanders, G. and Gregersen, H.B. (2001), "Bundling human capital with organizational context: the impact of international assignment experience on multinational firm performance and CEO pay", The Academy of Management Journal, Vol. 44 No. 3, pp. 493-511, available at: https://doi.org/10.2307/3069366

Chakrabarti, R., Subramanian, K., Yadav, K.P. and Yadav, Y. (2012), Executive Compensation in India: Handbook on Executive Compensation, Edward Elgar Publications, Gloucestershire.

Chauhan, Y., Dey, D.K. and Jha, R.R. (2016), "Board structure, controlling ownership, and business groups: evidence from India”, Emerging Markets Review, Vol. 27, pp. 63-83, available at: http://dx.doi.org/10.1016/j.ememar.2016.03.003

Cheung, Y.-L., Stouraitis, A. and Wong, A.W.S. (2005), "Ownership concentration and executive compensation in closely held firms: evidence from Hong Kong", Journal of Empirical Finance, Vol. 12 No. 4, pp. 511-532, available at: http://dx.doi.org/10.1016/j.jempfin.2004.10.001

Choi, J.J., Park, S.W. and Yoo, S.S. (2007), "The value of outside directors: evidence from corporate governance reform in Korea”, Journal of Financial and Quantitative Analysis, Vol. 42 No. 4, pp. 941-962, available at: https://doi.org/10.1017/S0022109000003458

Clifford, P. and Evans, R. (2002), "Non-executive directors: a question of independence", Corporate Governance: An International Review, Vol. 5 No. 4, pp. 224-231, available at: https://doi.org/10.1111/14 67-8683.00064

Combs, J.G., Penney, C.R., Crook, T.R. and Short, J.C. (2010), "The impact of family representation on CEO compensation", Entrepreneurship Theory and Practice, Vol. 34 No. 6, pp. 1125-1144, available at: https://doi.org/10.1111/j.1540-6520.2010.00417.x 
EIMBE 28,3

Conyon, M.J. and He, L. (2011), "Executive compensation and corporate governance in China", Journal of Corporate Finance, Vol. 17 No. 4, pp. 1158-1175, available at: http://dx.doi.org/10.10 16/j.jcorpfin.2011.04.006

Core, J.E., Guay, W.R. and Verrecchia, R.E. (2003), "Price versus non-price performance measures in optimal CEO compensation contracts", The Accounting Review, Vol. 78 No. 4, pp. 957-981.

Core, J.E., Holthausen, R.W. and Larcker, D.F. (1999), "Corporate governance, chief executive officer compensation, and firm performance", Journal of Financial Economics, Vol. 51 No. 3, pp. 371-406.

Davis, J.H., Schoorman, F.D. and Donaldson, L. (1997), "Toward a stewardship theory of management", The Academy of Management Review, Vol. 22 No. 1, pp. 20-47, available at: https://doi.org/10.23 $07 / 259223$

Donaldson, L. (1995), American Anti-management Theories of Organization: A Critique of Paradigm Proliferation, Cambridge University Press, Cambridge.

Donaldson, L. and Davis, J.H. (1991), "Stewardship theory or agency theory: CEO governance and shareholder returns”, Australian Journal of Management, Vol. 16 No. 1, pp. 49-64, available at: https://doi.org/10.1177/031289629101600103

Dorata, N.T. and Petra, S.T. (2008), "CEO duality and compensation in the market for corporate control”, Managerial Finance, Vol. 34 No. 5, pp. 342-353, available at: http://dx.doi.org/10.11 08/03074350810866216

Fabbri, F. and Marin, D. (2012), "What explains the rise in CEO pay in Germany? A panel data analysis for 1977-2009”, CESifo Working Paper Series No. 3757, CESifo Group, Munich.

Fama, E.F. (1980), “Agency problems and the theory of the firm”, Journal of Political Economy, Vol. 88 No. 2, pp. 288-307, available at: https://doi.org/10.2307/1837292

Fama, E.F. and Jensen, M.C. (1983), "Separation of ownership and control", Journal of Law and Economics, Vol. 26 No. 2, pp. 301-325.

Firth, M., Fung, P.M.Y. and Rui, O.M. (2007), "How ownership and corporate governance influence chief executive pay in China's listed firms", Journal of Business Research, Vol. 60 No. 7, pp. 776-785, available at: http://dx.doi.org/10.1016/j.jbusres.2007.01.014

Frey, B. (1997), "On the relationship between intrinsic and extrinsic work motivation”, International Journal of Industrial Organization, Vol. 15 No. 4, pp. 427-439.

Ghosh, A. (2006), "Determination of executive compensation in an emerging economy: evidence from India", Emerging Markets Finance and Trade, Vol. 42 No. 3, pp. 66-90, available at: https://doi.org/10.27 53/REE1540-496X420304

Ghosh, S. (2010), "Firm performance and CEO pay: evidence from Indian manufacturing", The Journal of Entrepreneurship, Vol. 19 No. 2, pp. 137-147.

Gomez-Mejia, L. and Wiseman, R.M. (1997), "Reframing executive compensation: an assessment and outlook", Journal of Management, Vol. 23 No. 3, pp. 291-374, available at: https://doi.org/10.11 77/014920639702300304

Grasse, N., Davis, T. and Ihrke, D. (2014), "Understanding the compensation of nonprofit executive directors: examining the influence of performance and organizational characteristics", Nonprofit Management and Leadership, Vol. 24 No. 3, pp. 377-398, available at: https://doi.org/10.10 02/nml.21099

He, L., Wright, S., Evans, E. and Crowe, S. (2009), "What makes a board independent? Australian evidence”, Accounting Research Journal, Vol. 22 No. 2, pp. 144-166, available at: https:/doi.org/10.11 08/10309610910987493

Holderness, C. and Sheehan, D. (1988), "The role of majority shareholders in publicly-held corporations: an exploratory analysis", Journal of Financial Economics, Vol. 20, pp. 317-346.

Houston, J., Lee, J. and Shan, H. (2016), "Shades of gray in board independence", available at: http:// clsbluesky.law.columbia.edu/2016/10/20/the-shades-of-gray-in-board-independence/ (accessed November 8, 2018). 
Houston, J.F., Lee, J. and Shan, H. (2017), "In search of board independence: former employees, shades of gray and director classifications revisited”, available at: http://dx.doi.org/10.2139/ ssrn.2824150 (accessed January 15, 2019).

Hsu, H.-H. and Wu, C.Y.-H. (2014), "Board composition, grey directors and corporate failure in the UK", The British Accounting Review, Vol. 46 No. 3, pp. 215-227, available at: https://doi.org/10.1016/j.bar.20 13.12 .002

Jaiswall, M. and Frith, M. (2009), "CEO pay, firm performance, and corporate governance in India's listed firms", International Journal of Corporate Governance, Vol. 1 No. 3, pp. 227-240, available at: https://doi.org/10.1504/IJCG.2009.029367

Jaiswall, S.S.K. and Bhattacharya, A.K. (2016), "Corporate governance and CEO compensation in Indian firms", Journal of Contemporary Accounting and Economics, Vol. 12 No. 2, pp. 159-175, available at: https://doi.org/https://doi.org/10.1016/j.jcae.2016.06.001

Jensen, M.C. and Meckling, W. (1976), "Theory of the firm: managerial behavior, agency costs, and ownership structure", Journal of Financial Economics, Vol. 3 No. 4, pp. 305-360.

Jensen, M.C. and Murphy, K.J. (1990a), “CEO incentives - it's not how much you pay, but how”, Harvard Business Review, May-June, pp. 138-153.

Jensen, M.C. and Murphy, K.J. (1990b), "Performance pay and top-management incentives", The Journal of Political Economy, Vol. 98 No. 2, p. 225-264.

Jiang, W. (2011), “Ownership structure and executive compensation in Canadian corporations”, The University of Saskatchewan, Saskatoon.

Kahneman, D. and Tversky, A. (1979), "Prospect theory: an analysis of decision under risk", Econometrica, Vol. 47 No. 2, p. 263-292.

Kaur, P. and Gill, S. (2008), "The Effects of ownership structure on corporate governance and performance: an empirical assessment in India”, National Foundation for Corporate Governance, New Delhi.

Khan, A., Mather, P. and Balachandran, B. (2012), "Managerial share ownership and operating performance: do independent and executive directors have different incentives?", Australian Journal of Management, Vol. 39 No. 1, pp. 47-71, available at: https://doi.org/10.1177/03128 96212463152

Kidder, D.L. and Buchholtz, A.K. (2002), "Can excess bring success? CEO compensation and the psychological contract”, Human Resource Management Review, Vol. 12 No. 4, pp. 599-617, available at: https://doi.org/10.1016/S1053-4822(02)00071-2

Kumar, N. and Singh, J.P. (2012), "Outside directors, corporate governance and firm performance: empirical evidence from India”, Asian Journal of Finance \& Accounting, Vol. 4 No. 2, pp. 39-55, available at: https://doi.org/10.5296/ajfa.v4i2.1737

Kumar, N. and Singh, J.P. (2013), "Effect of board size and promoter ownership on firm value: some empirical findings from India”, Corporate Governance, Vol. 13 No. 1, pp. 88-98.

Lazear, E.P. and Rosen, S. (1981), "Rank-order tournaments as optimum labor contracts”, Journal of Political Economy, Vol. 89 No. 5, pp. 841-864, available at: https://doi.org/10.1086/261010

Li, L. and Kuo, C.-S. (2017), "CEO equity compensation and earnings management: the role of growth opportunities”, Finance Research Letters, Vol. 20, pp. 289-295, available at: https://doi.org/10.10 16/j.frl.2016.10.013

Maassen, G.F. (1999), A Study on the Formal Independence and Convergence of One-tier and Two-tier Corporate Boards of Directors in the United States of America, the United Kingdom and the Netherlands (Third), Rotterdam School of Management, Amsterdam.

Mangel, R. and Singh, H. (1993), "Ownership structure, board relations and CEO compensation in large US corporations”, Accounting and Business Research, Vol. 23 No. 91A, p. 339-350.

Mehran, H. (1995), "Executive compensation structure, ownership, and firm performance”, Journal of Financial Economics, Vol. 38 No. 2, pp. 163-184, available at: https://doi.org/10.1016/0304-405X(94) 00809-F
Gray directors and executive compensation

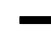


EIMBE 28,3

Miwa, Y. and Ramseyer, J.M. (2005), "Who appoints them, what do they do? Evidence on outside directors from Japan”, Journal of Economics and Management Strategy, Vol. 14 No. 2, pp. 299-337, available at: https://doi.org/10.1111/j.1530-9134.2005.00043.x

Narayanan, C. and Dubey, J. (2015), “Are Indian CEOs overpaid?”, Business Today, August 15, pp. 8-12.

O'Reilly, C.A., Main, B.G. and Crystal, G.S. (1988), "CEO compensation as tournament and social comparison: a tale of two theories", Administrative Science Quarterly, Vol. 33 No. 2, pp. 257-274, available at: https://doi.org/10.2307/2393058

Osi, C. (2009), "Family business governance and independent directors: the challenges facing an independent family business Board", University of Pennsylvania Journal of Business Law, Vol. 12, pp. 181-217.

Otten, J.A. (2007), "Theories on executive pay: a literature overview and critical assessment", No. 6969, Rotterdam School of Management, Erasmus University, Munich.

Ozkan, N. (2011), "CEO compensation and firm performance: an empirical investigation of UK panel data", European Financial Management, Vol. 17 No. 2, pp. 260-285, available at: https://doi.org/10.11 11/j.1468-036X.2009.00511.x

Parthasarathy, A., Bhattacherjee, D. and Menon, K. (2006), "Executive compensation, firm performance and governance", Economic and Political Weekly, Vol. 41 No. 39, pp. 4139-4147.

Pfeffer, J. (1981), Power in Organizations, Pitman Publishing Corporation, London.

Prendergast, C. (1999), "The provision of incentives in firms", Journal of Economic Literature, Vol. 37 No. 1, pp. 7-63.

Raghunandan, K., Rama, D.V. and Read, W.J. (2001), “Audit committee composition, 'gray directors,' and interaction with internal auditing", Accounting Horizons, Vol. 15 No. 2, pp. 105-118, available at: https://doi.org/10.2308/acch.2001.15.2.105

Raithatha, M. and Komera, S. (2016), "Executive compensation and firm performance: evidence from Indian firms", IIMB Management Review, Vol. 28 No. 3, pp. 160-169, available at: https://doi.org/10.10 16/j.iimb.2016.07.002

Ramaswamy, K., Veliyath, R. and Gomes, L. (2000), "A study of the determinants of CEO compensation in India”, Management International Review, Vol. 40 No. 2, pp. 167-191.

Roberts, D.R. (1956), "A general theory of executive compensation based on statistically tested propositions", The Quarterly Journal of Economics, Vol. 70 No. 2, pp. 270-294.

Rose, C. (2005), "Managerial ownership and firm performance in listed Danish firms: in search of the missing link”, European Management Journal, Vol. 23 No. 5, pp. 542-553, available at: https://doi.org/10.10 16/j.emj.2005.09.009

Rosen, S. (1981), "The economics of superstars", The American Economic Review, Vol. 71 No. 5, pp. 845-858.

Rousseau, D.M. (1998), “The 'problem' of the psychological contract considered”, Journal of Organizational Behavior, Vol. 19 No. S1, pp. 665-671.

Ryan, H.E. and Wiggins, R.A. (2004), "Who is in whose pocket? Director compensation, board independence, and barriers to effective monitoring", Journal of Financial Economics, Vol. 73 No. 3, pp. 497-524, available at: https://doi.org/10.1016/j.jfineco.2003.11.002

Saravanan, P., Srikanth, M. and Avabruth, S.M. (2017), "Compensation of top brass, corporate governance and performance of the Indian family firms - an empirical study", Social Responsibility Journal, Vol. 13 No. 3, pp. 529-551, available at: https://doi.org/10.1108/SRJ -03-2016-0048

Sarkar, J. (2009), "Board independence \& corporate governance in India: recent trends \& challenges ahead", Indian Journal of Industrial Relations, Vol. 44 No. 4, pp. 576-592.

Sarkar, J., Sarkar, S. and Sen, K. (2012), "A corporate governance index for large listed companies in India”, WP-2012-009, Indira Gandhi Institute of Development Research, Mumbai. 
Sarpal, S. (2015), "Determinants of corporate board independence: empirical evidence from India", Management and Labour Studies, Vol. 40 Nos 1-2, pp. 52-74, available at: https://doi.org/10.11 77/0258042X15601533

Shivdasani, A. and Yermack, D. (1999), "CEO involvement in the selection of new board members: an empirical analysis”, The Journal of Finance, Vol. 54 No. 5, pp. 1829-1853, available at: https://doi.org/1 $0.1111 / 0022-1082.00168$

Srivastava, N.K. (2015), "Does governance structure have any effect on firm performance during the financial crisis: evidence from selected Indian companies”, Journal of Strategy and Management, Vol. 8 No. 4, pp. 368-383, available at: https://doi.org/10.1108/JSMA-02-2015-0014

Sur, S., Lvina, E. and Magnan, M. (2013), "Why do boards differ? Because owners do: assessing ownership impact on board composition”, Corporate Governance: An International Review, Vol. 21 No. 4, pp. 373-389, available at: https://doi.org/10.1111/corg.12021

Tien, C., Chen, C.-N. and Chuang, C.-M. (2013), “A study of CEO power, pay structure, and firm performance”, Journal of Management and Organization, Vol. 19 No. 4, pp. 424-453, available at: http://dx.doi.org/10.1017/jmo.2013.30

Ueda, R. (2015), "How is corporate governance in Japan changing? Developments in listed companies and roles of institutional investors", OECD Corporate Governance Working Papers, Paris, available at: http://dx.doi.org/10.1787/5irw7i3s37hh-en (accessed August 23, 2017).

Ungson, G.R. and Steers, R.M. (1984), "Motivation and politics in executive compensation", The Academy of Management Review, Vol. 9 No. 2, pp. 313-323, available at: https://doi.org/10.23 $07 / 258444$

Veliyath, R. and Ramaswamy, K. (2000), "Social embeddedness, overt and covert power and their effects on CEO pay: an empirical examination among family businesses in India”, Family Business Review, Vol. XIII No. 4, pp. 293-312.

Yammeesri, J. and Herath, S.K. (2010), "Board characteristics and corporate value: evidence from Thailand”, Corporate Governance, Vol. 10 No. 3, pp. 279-292, available at: http://dx.doi.org/10.11 08/14720701011051910

Yeung, J.C.K. (2018), "Nonlinear effect of board size on corporate performance: impact of the cultural backgrounds of directors in Hong Kong”, Asia-Pacific Journal of Financial Studies, Vol. 47 No. 1, pp. 107-131, available at: https://doi.org/10.1111/ajfs.12205

Zakaria, H., Ramli, F. and Ameer, R. (2010), "A new perspective on board composition and firm performance in an emerging market”, Corporate Governance: The International Journal of Business in Society, Vol. 10 No. 5, pp. 647-661, available at: https://doi.org/10.11 08/14720701011085607

Zhao, A. and Brehm, A.J. (2011), "Cumulative voting and the conflicts between board and minority shareholders”, Managerial Finance, Vol. 37 No. 5, pp. 465-473, available at: http://dx.doi.org/10.11 08/03074351111126942

\section{Corresponding author}

Nandan Prabhu can be contacted at: nandan.prabhu@manipal.edu
Gray directors and executive compensation 